\title{
Agomelatin Yetişkin Sıçanlarda Skopolamin Kaynaklı Öğrenme ve Hafıza Bozukluğunu Tersine Çevirir
}

\section{Agomelatine Reverses Scopolamine-Induced Learning and Memory Impairment in Adult Rats}

\author{
${ }^{1}$ Sinan SARAL, ${ }^{2}$ Atilla TOPÇU, ${ }^{3}$ Ayssegül SÜMER, ${ }^{1}$ Ali Koray KAYA, \\ ${ }^{2}$ Aykut ÖZTÜRK, ${ }^{4}$ Esra PINARBAŞ
}

\begin{abstract}
${ }^{1}$ Recep Tayyip Erdogan University, Faculty of Medicine, Department of Physiology, Rize, Turkey ${ }^{2}$ Recep Tayyip Erdogan University, Faculty of Medicine, Department of Pharmacology, Rize, Turkey ${ }^{3}$ Recep Tayyip Erdogan University, Faculty of Health Sciences, Department of Nursing, Rize, Turkey ${ }^{4}$ Recep Tayyip Erdogan University, Faculty of Medicine, Department of Biochemistry, Rize, Turkey
\end{abstract}

Sinan Saral: https://orcid.org/0000-0002-0961-1903 Atilla Topçu: https://orcid.org/0000-0003-4730-5015 Ayşegül Sümer: https://orcid.org/0000-0003-4918-4368 Ali Koray Kaya: https://orcid.org/0000-0003-2433-5115 Aykut Öztürk: https://orcid.org/0000-0003-4515-6968 Esra Pınarbaş: https://orcid.org/0000-0001-6231-7597

\section{ÖZ}

Amaç: Agomelatin, melatonin reseptör (MT1 ve MT2) agonisti ve serotonin reseptör (5-HT2C) antagonisti olan antidepresan bir ilaçtır. Artan kanıtlar, agomelatinin nöroprotektif ve nöromodülatör etkiye sahip olduğunu göstermektedir. $\mathrm{Bu}$ çalışmada skopolamin indüklü bilişsel yetmezlik oluşturulan sıçanlarda agomelatinin potansiyel etkileri araştırılmıştır.

Materyal ve Metot: Erişkin erkek sıçanlara 21 gün süreyle skopolamin $(1 \mathrm{mg} / \mathrm{kg})$ ve agomelatin $(40 \mathrm{mg} / \mathrm{kg})$ uygulandı. İlaç uygulamalarını takiben sıçanlar bilişsel davranışların değerlendirilebilmesi amacıyla yeni nesne tanıma (YNT) ve Morris su labirenti (MSL) testine tabi tutuldu. İlave olarak, beyin nörokimyasal analizleri için hipokampus ve prefrontal kortekste beyin-türevi nörotrofik faktör (BDNF) ve asetilkolin ( $\mathrm{ACh}$ ) düzeyleri değerlendirildi.

Bulgular: Skopolamin hem uzamsal hafizayı hem de ayırt etme indeksini önemli ölçüde azalttı $(p<0,05)$. Agomelatin tedavisi uzamsal hafiza performansını ve keşif süresini arttırd1, ancak ayrımcılık indeksini etkilemedi $(\mathrm{P}>0,05)$. Ayrica agomelatin, skopolamin grubuna kıyasla hem hipokampusta hem de prefrontal kortekste BDNF düzeylerini önemli ölçüde arttırdı (sırasıyla $\mathrm{p}<0,05, \mathrm{p}<0,01$ ). Diğer yandan grupların $\mathrm{ACh}$ düzeyleri arasında istatistiksel olarak anlamlılik bulunmadi $(p>0,05)$.

Sonuç: Birlikte ele alındığında, bu sonuçlar agomelatinin skopolamin kaynaklı hafiza yetmezliğinin hafifletilmesinde belirgin rol oynadığını göstermiştir. Bu nedenle, agomelatinin bilişsel yetmezliğin önlenmesinde potansiyel bir ajan olabileceğini öne sürüyoruz.

Anahtar Kelimeler: Agomelatin, asetilkolin, BDNF, bellek, bilişsel yetmezlik

\section{ABSTRACT}

Objective: The antidepressant agomelatine agent is a melatonin receptor (MT1 and MT2) agonist and a serotonin receptor (5-HT2C) antagonist. Increasing evidence shows that agomelatine has neuroprotective and neuromodulatory effects. In this study, the potential effects of agomelatine in rats with scopolamine-induced cognitive impairment were investigated.

Materials and Methods: Adult male rats were administered scopolamine $(1 \mathrm{mg} / \mathrm{kg})$ and agomelatine $(40 \mathrm{mg} / \mathrm{kg})$ for 21 days. After drug administration, rats were subjected to new object recognition (NOR) and Morris water maze (MWM) tests in order to evaluate cognitive behaviors. In addition, brain-derived neurotrophic factor (BDNF) and acetylcholine (ACh) levels in the hippocampus and prefrontal cortex were evaluated.

Results: Scopolamine significantly decreased both spatia memory and discrimination index $(\mathrm{p}<0.05)$. Agomelatine treatment increased spatial memory performance and exploration time, but did not affect the discrimination index $(\mathrm{P}>0.05)$. In addition, agomelatine significantly increased BDNF levels in both hippocampus and prefrontal cortex compared to the scopolamine group $(\mathrm{p}<0.05, \mathrm{p}<0.01$, respectively). On the other hand, there was no statistically significant difference between the ACh levels of the groups ( $>0.05$ ).

Conclusion: Taken together, these results demonstrated that agomelatine plays a important role in alleviating scopolamine-induced memory impairment. Therefore, we suggest that agomelatine may be a potential agent in the prevention of cognitive impairment.

Keywords: Acetylcholine, agomelatine, BDNF, cognitive impairment, memory
Sorumlu Yazar / Corresponding Author:

Sinan Saral

Dr, RTE Üniversitesi, Tıp Fakültesi 53100, Rize/Türkiye

Tel: +90 $04642123009-3214$

E-mail: sinan.saral@erdogan.edu.tr
Yayın Bilgisi / Article Info:

Gönderi Tarihi/ Received: 27/07/2021

Kabul Tarihi/ Accepted: 25/10/2021

Online Yayın Tarihi/ Published: 01/12/2021 


\section{INTRODUCTION}

Dementia is a mental disability that is characterized by a decrease in memory and other higher cognitive functions. Alzheimer's disease (AD) is the most common cause of global dementia and is a progressive neurodegenerative disease primarily seen in elderly people. ${ }^{1}$ The main pathophysiological processes in the progression of the disease are cholinergic deterioration, synapse degeneration, accumulation of amyloid plaques, and abnormal phosphorylation of tau protein. ${ }^{2,3}$ Loss of cholinergic neurons has been associated with early cognitive function losses. ${ }^{4}$

Scopolamine is a non-selective muscarinic receptor antagonist adversely affecting learning and shortterm memory processes in humans and rodents. ${ }^{5}$ Moreover, scopolamine is widely used for the investigation of the pathophysiological mechanisms of some neurodegenerative diseases, including AD. The ability of scopolamine to cause cognitive deficits makes it a valid pharmacological agent for triggering cognitive deficits. ${ }^{6}$ In a previous study, it was reported that scopolamine significantly increased AChE activity while decreasing ACh level in adult mouse cortex and hippocampus. ${ }^{7}$ Similarly, scopolamine has been reported to impair cholinergic neurotransmission by increasing AchE activity in mice. ${ }^{8}$ On the other hand, scopolamine has been shown to disrupt not only the brain's cholinergic system, but also neurotrophin synthesis, which plays an important role in synaptic plasticity. In this context, it was reported in a previous study that scopolamine impairs cognitive performance by significantly reducing the expression of brain-derived neurotrophic factor (BDNF), an important neurotrophic factor in the rodent hippocampus. ${ }^{9}$ Therefore, compounds with the potential for regulation of the cholinergic system and BDNF activity in the prevention of disorders characterized by cognitive impairment are coming into focus.

Agomelatine is a potential melatonin (MT) receptor (MT1 and MT2) agonist and serotonin (5-HT) receptor (5-HT2C) antagonist. ${ }^{10}$ It has been stated that agomelatine may regulate cognitive functions by affecting limbic regions, including the hippocampus. ${ }^{11}$ Experimental studies have demonstrated the potential of agomelatine to improve learning and memory performance. ${ }^{12}$ These directional effects of agomelatine have been associated with increased BDNF expression in the hippocampus. ${ }^{13,14}$ Similarly, agomelatine has been shown to play a key role in regulating impaired cognitive functions by regulating synaptic plasticity. ${ }^{15}$ On the other hand, previous studies have reported that agomelatine limits cholinergic impairment in mice with experimental learning and memory deficits. ${ }^{16}$ However, the effects of agomelatine on memory functions and the cholinergic system in dementia model rats are not clear. The aim of this study is to examine the effects of agomelatine on neurocognitive behaviors, cholinergic system and hippocampal BDNF levels in rats with experimental amnesia induced by scopolamine.

\section{MATERIALS AND METHODS}

Animals and Ethical Approval: 32 male Sprague Dawley rats weighing 300-350 g were used in the study. Animals were housed in standard cages in 4 groups with $8(n=8)$ rats in each group. The rats were housed in rooms with standardized temperature $\left(22 \pm 3{ }^{\circ} \mathrm{C}\right)$ and light (12 hours light/dark) throughout the experiment. Animals were fed standard pellet feed and provided ad libitum access to water. The rats were taken to the behavioral laboratory one week before the cognitive behavioral tests for adaptation

Drug and Chemicals: Agomelatine (valdoxan, Les Laboratoires Servier, France) was purchased from local pharmacy. Scopolamine was obtained from Sigma-Aldrich (MO, USA). Acetylcholine (ACh) and BDNF ELISA kits were purchased from Elabscience (Elabscience. Texas, USA).

Experimental Design: Study groups; I) control, II) scopolamine, III) agomelatine, IV) scopolamine+agomelatine. Scopolamine was administered intraperitoneally (i.p) at a dose of $1 \mathrm{mg} / \mathrm{kg} 30 \mathrm{mi}-$ nutes before agomelatine administration. Then agomelatine was administered at a dose of $40 \mathrm{mg} / \mathrm{kg}$ by oral gavage. The agomelatine dose was determined based on a previous study. ${ }^{17}$ Drug administrations were carried out once a day for 21 days. Subsequently, new object recognition and morris swimming tests were performed. Following the end of the behavioral tests, the subjects were euthanized under highdose anesthesia. Then the skull was opened and the hippocampus and prefrontal cortex were removed in the cold chain. Tissues were stored at $-80{ }^{\circ} \mathrm{C}$ until evaluation. At the analysis stage, homegenates were prepared from tissues under suitable conditions and analyzes were carried out.

New object recognition (NOR) test: This test was performed as detailed in previous studies. ${ }^{18,19}$ Behavioral tests were conducted in a dim and quiet room monitored by a camera system. The platform used in the experiment $(90 \mathrm{~cm}$ x $90 \mathrm{~cm} \mathrm{x} 45 \mathrm{~cm}$ ) was made of plexiglass. Experiments were performed on three consecutive days following drug administrations. 1st day (familiarization session); The rats were placed on the platform for 5 minutes and allowed to get used to the apparatus. 2nd day (training session); Two identical objects were placed at the corners of the platform and allowed for exploration for $5 \mathrm{mi}$ nutes. 3rd day (test session); one of the familiar ob- 
jects was replaced with a different one and the rats were allowed to explore for $3 \mathrm{~min}$. Discovery of an object was defined as contact with the nose and/or moving the nose to the object within a range of up to a maximum of $1 \mathrm{~cm}$. Before each test, the objects and platform were cleaned with $70 \%$ ethanol solution. The tests were carried out at the same times each day. The behavior of the rats was recorded using the behavior monitoring software ANY maze (ANY maze 5.2, Dublin / Ireland). At the analysis stage, the exploratory behavior and discrimination index of the rats were calculated.

Morris water maze (MWM) test: The experimental protocol of this study was prepared by considering our previous study. ${ }^{20}$ briefly; a $150 \mathrm{~cm}$ diameter water pool was used in the experiment. The escape platform $(15 \mathrm{~cm}$ in diameter) was placed in the middle of the determined quarter. In the pre-training phase, rats were placed in water and expected to reach the target quadrant. Rats that found the platform were allowed to stay there for 30 seconds. In the next step (acquisition trial), the water level was raised by $2 \mathrm{~cm}$. For the following 5 days, the rats were released into the water 3 times a day to reach the platform. The time taken to find the hidden platform for 5 days was scored as escape latency. On the 6th day (probe trial), the platform was removed from the water and the rats were left in the water for 60 seconds and the time spent in the target quadrant where the platform was located was recorded. Test recordings were obtained using the animal behavior software program ANY maze (ANY maze 5.2, Dublin / Ireland). As a result, escape latency ( $\mathrm{sec})$, time spent in the target quadrant (sec), number of entries into the target quadrant, and average velocity in the target quadrant $(\mathrm{m} / \mathrm{sec})$ were calculated.

Statistical Analysis: All statistical analyzes were performed with the GraphPad Prism 8.0 program (San Diego, CA, USA). Experimental results are given as Standard Error of the Mean $( \pm$ SEM). Normal distribution fitting of the data was evaluated with the Shapiro-Wilk test. One-way ANOVA followed by post-hoc tukey test was used to determine the difference between the experimental groups. $\mathrm{P}<0.05$ was considered significant.

\section{RESULTS}

\section{Effects of agomelatine on exploratory behavior and} spatial memory in rats

The effect of agomelatine on recognition memory was evaluated with the NOR test. In this context, scopolamine decreased the total exploration time and discrimination index (Figure 1A, $\mathrm{p}<0.05$ ). On the other hand, agomelatine treatment increased the total exploration time $(\mathrm{P}<0.05)$ but did not significantly affect the discrimination index (Figure 1B, $\mathrm{P}>0.05$ ).

The effect of agomelatine on spatial memory is shown in Figure 2. In the acquisition trial, the escape latency time of the scopolamine group was significantly higher than the control group (Figure 2A, $\mathrm{p}<0.05$ ). However, the escape latency time of the scopolamine+agomelatine group was significantly reduced compared to the scopolamine group $(p<0.05)$. In the probe trial, we found that the time spent in the target quadrant was lower in the scopolamine group than in the control (Figure 2B, $\mathrm{p}<0.05)$. In contrast, the scopolamine+agomelatine group remained longer in the target quadrant compared to the scopolamine group $(p<0.05)$. Similarly, significance was determined between the number of rats entering the target quadrant. Accordingly, while the number of entries into the target quadrant was significantly lower in the scopolamine group, ago-
A

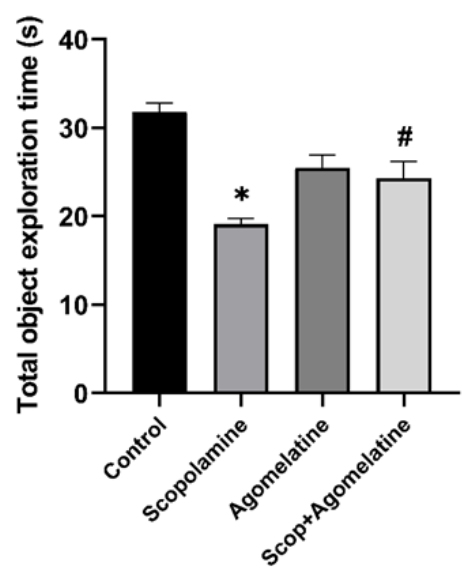

B

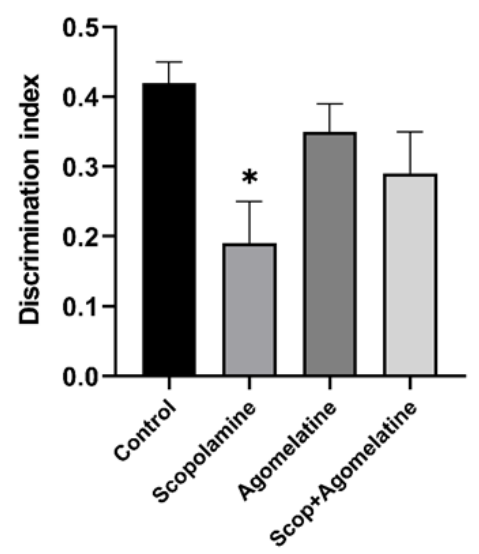

Figure 1. Effect of agomelatine on scopolamine-induced object recognition memory impairment. A: Total time spent exploring both objects, B: Discrimination index ${ }^{*} \mathrm{p}<0.05$ vs control group, $\# \mathrm{p}<0.05$ vs scopolamine group 
A

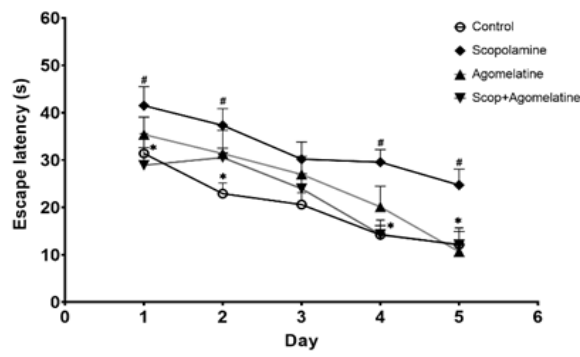

C

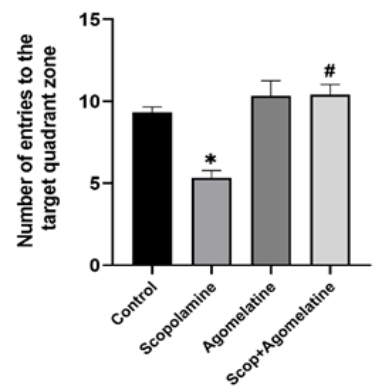

B

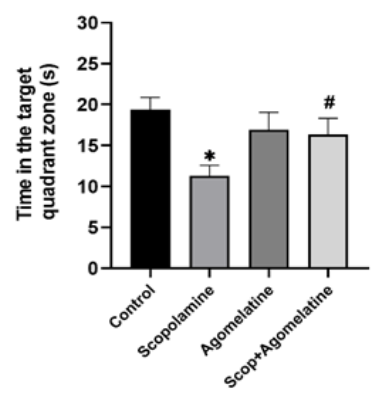

D

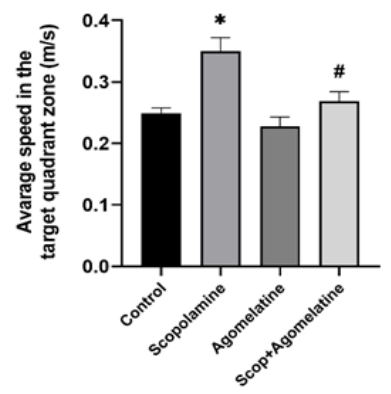

Figure 2. Effect of agomelatine on scopolamine-induced spatial memory impairment. A: Escape latency (s) during acquisition trials. B: Time spent in the target quadrant in the probe trial (s). C: The number of entries to the target quadrant. D: Average speed $(\mathrm{m} / \mathrm{s})$ in the target quadrant. $* \mathrm{p}<0.05$ vs control group, \#p $<0.05$ vs scopolamine group.

melatine treatment increased the number of entries into the target quadrant (Figure $1 \mathrm{C}, \mathrm{p}<0.05$ ). In addition, scopolamine increased the mean speed in the target quadrant, while agomelatine treatment significantly decreased the mean speed (Figure 1D, $\mathrm{p}<0.05)$.

BDNF levels in the hippocampus and prefrontal cortex

BDNF and ACh levels were measured in hippocampal and prefrontal cortex homogenates of rats. Compared to the control group, scopolamine did not significantly affect the BDNF level in the hippocampus $(p>0.05)$, but decreased it in the prefrontal cortex
(Figure 3, $\mathrm{P}<0.05)$. Moreover, agomelatine treatment significantly increased BDNF levels in both hippocampus and prefrontal cortex compared with the scopolamine group $(\mathrm{p}<0.05, \mathrm{p}<0.01$, respectively).

\section{ACh levels in the hippocampus and prefrontal cor- tex \\ We observed that administration of $1 \mathrm{mg} / \mathrm{kg}$ scopola- mine and $40 \mathrm{mg} / \mathrm{kg}$ agomelatine for 21 days did not cause statistically significant changes in ACh levels in the hippocampus and prefrontal cortex. (Figure 4, $\mathrm{p}>0.05)$.}

A

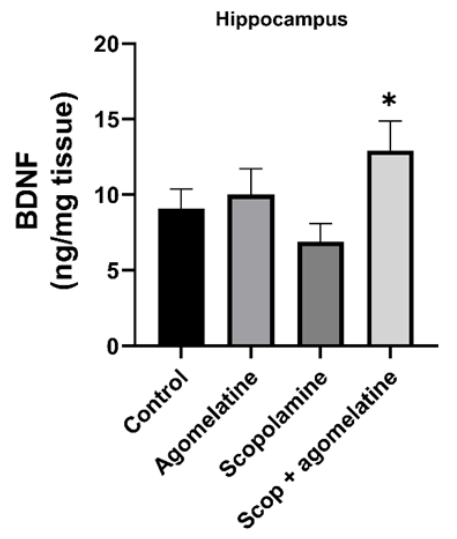

B

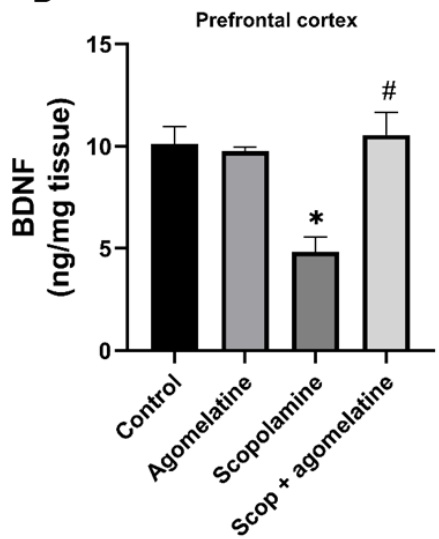

Figure 3. Effect of agomelatine on BDNF level in scopolamine-induced memory impairment in rats. A: Hippocampus, B: Prefrontal cortex $* \mathrm{p}<0.05$ vs control group, $\# \mathrm{p}<0.01$ vs scopolamine group. 
A

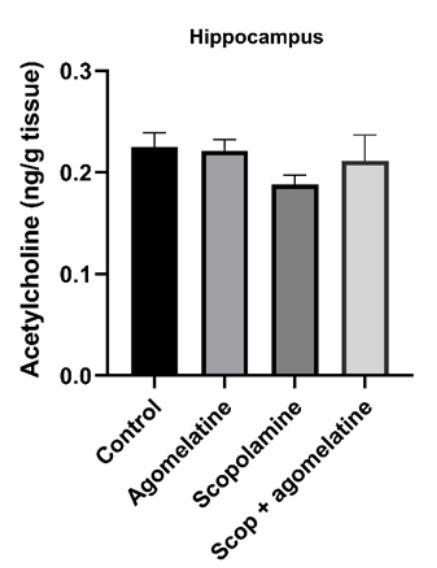

B

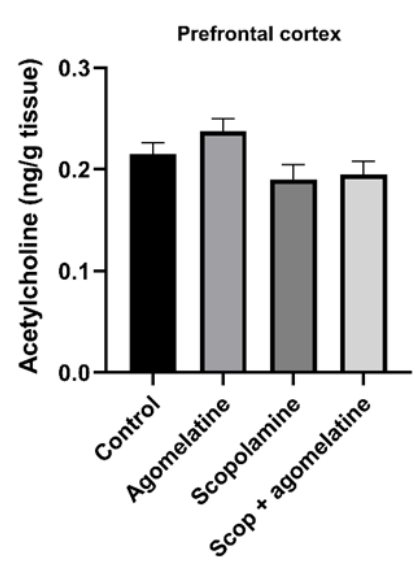

Figure 4. Effect of agomelatine on acetylcholine level in scopolamine-induced memory impairment in rats. A: Hippocampus, B: Prefrontal cortex

\section{DISCUSSION AND CONCLUSION}

In this study, we examined the behavioral and neurochemical effects of long-term agomelatine administration on scopolamine-induced memory impairment in rats. Our results revealed that the muscarinic receptor antagonist scopolamine weakened the memory performance of rats. However, agomelatine treatment significantly improved cognitive impairment.

The scopolamine-induced dementia model is widely used to explore the potential of therapeutic agents to treat $\mathrm{AD}$. It has been reported that scopolamine causes learning and memory impairment with dysfunction in cortical cholinergic neurons.Moreover, this effect has been mainly associated with the inhibition of muscarinic receptor signaling pathways. ${ }^{21}$ Previous studies have shown that scopolamine impairs the spatial memory of rodents in the MWM test. ${ }^{22,23}$ Similarly, scopolamine has been reported to decrease the recognition index in the object recognition task. ${ }^{24}$ Therefore, in our study, the effect of agomelatine on scopolamine-induced learning and memory impairment was examined using both MWM and NOR tasks. Increasing evidence has revealed that long-term use of agomelatine under physiological conditions exerts beneficial effects by causing structural changes in the hippocampus of adult rats. ${ }^{17}$ Scopolamine has been shown to cause decreased expression of phosphorylated cAMP response element binding protein (CREB) and BDNF in the rodent hippocampus and frontal cortex. ${ }^{8,25}$ In previous studies, agomelatine was shown to activate BDNF signaling in regulating cognitive functions in physiological and pathophysiological conditions. ${ }^{26,27}$ In our results, we found that agomelatine significantly increased BDNF levels in the prefrontal cor- tex.

In previous reports, scopolamine was shown to cause memory impairment by affecting cholinergic pathways. ${ }^{28}$ It has been reported that the loss of cholinergic neurons in the hippocampus and prefrontal cortex causes decreased ACh synthesis, storage and release, and this situation is associated with learning deficits. ${ }^{29}$ Recent studies showed that scopolamine decreases ACh synthesis and increases AChE enzyme activity. ${ }^{8,30}$ In our study, we evaluated the effects of agomelatine on the cholinergic system in rats with scopolamine-induced cognitive impairment. In this context, we measured ACh levels in rat hippocampal and prefrontal cortex homogenates. To the best of our knowledge, there is no research on the effect of agomelatine on ACh levels in the hippocampus and prefrontal cortex in the same experimental setup. However, in a previous study, it was reported that agomelatine decreased AChE activity in its neuroprotective effect against vascular dementia due to chronic cerebral hypoperfusion. ${ }^{16}$ This result supports the hypothesis that agomelatine can increase ACh level. However, in our study, agomelatine did not significantly change ACh levels in the hippocampus and prefrontal cortex. This indicates a limited role for ACh in the modulating effect of agomelatine on cognitive functions.

In conclusion, our findings revealed that agomelatine can alleviate scopolamine-induced cognitive impairment in adult rats. Therefore, agomelatine may have a potential for use in therapy for the prevention and/ or treatment of diseases characterized by loss of cognitive function.

Ethics Committee Approval: The study was approved by the Recep Tayyip Erdogan University Animal 
Experiments Local Ethics Committee (Date: 26.02.2021, decision no: 2021/03).

Conflict of Interest: No conflict of interest was declared by the authors.

Author Contributions: Concept - SS; Supervision AT, AS, AKK, AÖ; Materials - SS, AT; Data Collection and Processing - SS, AKK, EP, AÖ, AT; Analysis and Interpretation - SS, AS, EP; Writing SS.

Peer-review: Externally peer-reviewed.

\section{REFERENCES}

1. Deture MA, Dickson DW. The neuropathological diagnosis of Alzheimer' s disease. Mol Neurodegener. 2019;5:1-18.

2. Grimm A, Mensah-Nyagan AG, Eckert A. Alzheimer, mitochondria and gender. Neurosci Biobehav Rev. 2016;67:89-101.

3. Dos Santos TC, Gomes TM, Pinto BAS, Camara AL, De Andrade Paes AM. Naturally occurring acetylcholinesterase inhibitors and their potential use for Alzheimer's disease therapy. Front Pharmacol. 2018;9:1-14.

4. Craig LA, Hong NS, McDonald RJ. Revisiting the cholinergic hypothesis in the development of Alzheimer's disease. Neurosci Biobehav Rev. 2011;35(6):1397-1409.

5. Klinkenberg I, Blokland A. The validity of scopolamine as a pharmacological model for cognitive impairment: A review of animal behavioral studies. Neurosci Biobehav Rev. 2010;34 (8):1307-1350.

6. Haider S, Tabassum S, Perveen T. Scopolamineinduced greater alterations in neurochemical profile and increased oxidative stress demonstrated a better model of dementia: A comparative study. Brain Res Bull. 2016;127:234-247.

7. Tota SK, Hanif K, Kamat PK, Najmi AK, Nath C. Role of central angiotensin receptors in scopolamine-induced impairment in memory, cerebral blood flow, and cholinergic function. Psychopharmacology. 2012;222(2):185-202.

8. Lu C, Wang Y, Xu T, et al. Genistein ameliorates scopolamine-induced amnesia in mice through the regulation of the cholinergic neurotransmission, antioxidant system and the ERK/CREB/ BDNF signaling. Front Pharmacol. 2018;9(10):111.

9. Chen BH, Park JH, Lee TK, et al. Melatonin attenuates scopolamine-induced cognitive impairment via protecting against demyelination through BDNF-TrkB signaling in the mouse dentate gyrus. Chem Biol Interact. 2018;285(1):8-13.

10.Papp M, Gruca P, Boyer PA, Mocaer E. Effect of agomelatine in the chronic mild stress model of depression in the rat. Neuropsychopharmacology. 2003;28(4):694-703.
11. Rainer Q, Xia L, Guilloux JP, et al. Beneficial behavioural and neurogenic effects of agomelatine in a model of depression/anxiety. Int $\mathbf{J}$ Neuropsychopharmacol. 2012;15(3):321-335.

12. Can ÖD, Üçel Uİ, Özkay ÜD, Ulupınar E. The effect of agomelatine treatment on diabetesinduced cognitive impairments in rats: Concomitant alterations in the hippocampal neuron numbers. Int J Mol Sci. 2018;19(8):2461.

13. Molteni R, Calabrese F, Pisoni S, et al. Synergistic mechanisms in the modulation of the neurotrophin BDNF in the rat prefrontal cortex following acute agomelatine administration. World J Biol Psychiatry. 2010;11(2):148-153.

14. Gumuslu E, Mutlu O, Sunnetci D, et al. The antidepressant agomelatine improves memory deterioration and upregulates CREB and BDNF gene expression levels in unpredictable chronic mild stress (UCMS)-exposed mice. Drug Target Insights. 2014;(8):11-21.

15. Martin V, Allaïli N, Euvrard M, et al. Effect of agomelatine on memory deficits and hippocampal gene expression induced by chronic social defeat stress in mice. Sci Rep. 2017;8(3):1-11.

16. Gupta S, Singh P, Sharma B, Sharma B. Neuroprotective Effects of Agomelatine and Vinpocetine Against Chronic Cerebral Hypoperfusion Induced Vascular Dementia. Curr Neurovasc Res. 2015;12(3):240-252.

17. Özkay ÜD, Söztutar E, Can ÖD, Üçel UI, Öztürk Y, Ulupinar E. Effects of long-term agomelatine treatment on the cognitive performance and hippocampal plasticity of adult rats. Behav Pharmacol. 2015;26:469-480

18. Ennaceur A, Delacour J. A new one-trial test for neurobiological studies of memory in rats. 1: Behavioral data. Behav Brain Res. 1988;31(1):47 -59 .

19. Tian SW, Xu F, Gui SJ. Apelin-13 reverses memory impairment and depression-like behavior in chronic social defeat stressed rats. Peptides. 2018;108:1-6

20. Saral S, Topçu A, Alkanat M, et al. Apelin-13 activates the hippocampal BDNF/TrkB signaling pathway and suppresses neuroinflammation in male rats with cisplatin-induced cognitive dysfunction. Behav Brain Res. 2021;408:113290.

21. Jafarian S, Ling KH, Hassan Z, Perimal-Lewis L, Sulaiman MR, Perimal EK. Effect of zerumbone on scopolamine-induced memory impairment and anxiety-like behaviours in rats. Alzheimer's Dement Transl Res Clin Interv. 2019;5:637-643.

22. Janas AM, Cunningham SC, Duffy KB, et al. The cholinesterase inhibitor, phenserine, improves Morris water maze performance of scopolamine-treated rats. Life Sci. 2005;76(10):10731081.

23. Lee JC, Park JH, Ahn JH, et al. Effects of chro- 
nic scopolamine treatment on cognitive impairment and neurofilament expression in the mouse hippocampus. Mol Med Rep. 2018;17(1):16251632.

24. Kim DH, Ryu JH. Differential effects of scopolamine on memory processes in the object recognition test and the Morris water maze test in mice. Biomol Ther. 2008;16(3):173-178.

25. Ko YH, Kwon SH, Lee SY, Jang CG. Isoorientin improves scopolamine-induced cognitive impairments by restoring the cholinergic system, antioxidant defense, and p-CREB/BDNF signaling in the hippocampus and frontal cortex. Arch Pharm Res. 2019;42(8):722-731.

26. Gumuslu E, Mutlu O, Sunnetci D, et al. The antidepressant agomelatine improves memory deterioration and upregulates CREB and BDNF gene expression levels in unpredictable chronic mild stress (UCMS)-exposed mice. Drug Target Insights. 2014;2014(8):11-21.

27. Lu Y, Ho CS, McIntyre RS, Wang W, Ho RC. Agomelatine-induced modulation of brainderived neurotrophic factor (BDNF) in the rat hippocampus. Life Sci. 2018;210(8):177-184.

28. Lee B, Shim I, Lee H, Hahm DH. Rehmannia glutinosa ameliorates scopolamine-induced learning and memory impairment in rats. J Microbiol Biotechnol. 2011;21(8):874-883.

29. Klaassens BL, van Gerven JMA, Klaassen ES, van der Grond J, Rombouts SARB. Cholinergic and serotonergic modulation of resting state functional brain connectivity in Alzheimer's disease. Neuroimage. 2019;199(10):143-152.

30. Wong-Guerra M, Jiménez-Martin J, FonsecaFonseca LA, et al. JM-20 protects memory acquisition and consolidation on scopolamine model of cognitive impairment. Neurol Res. 2019;41 (5):385-398. 